УдК 504.064.3:621.039

Я. Ю. Бєлов, В. І. Богорад, Т. В. Литвинська, А. В. Носовський, О. Ю. Слепченко, О. Є. Трофімова

Державний науково-технічний центр з ядерної та радіаційної безпеки, м. Київ, Україна

\section{Аналіз досвіду використання мобільних лабораторій радіаційного контролю}

Наведено результати аналізу технічного та методичного оснащення мобільних радіологічних лабораторій, що експлуатуються провідними в сфері використання ядерної енергії державами з метою забезпечення ефективної роботи автомобіля радіаційної розвідки RanidSONNI. Висвітлено досвід використання мобільної лабораторії під час проведення чемпіонату Європи з футболу, що відбувався в Києві. Визначено можливі напрямки використання мобільної лабораторії.

Ключові слова: мобільна радіологічна лабораторія, радіаційний захист, радіаційний моніторинг, джерела іонізуючого випромінювання.

Я. Ю. Белов, В. И. Богорад, Т. В. Литвинская, А. В. Носовский, А. Ю. Слепченко, Е. Е. Трофимова

Анализ опыта использования мобильных лабораторий радиационного контроля

Представлены результаты анализа технического и методического оснащения мобильных радиологических лабораторий, которые эксплуатируются ведущими государствами в сфере использования ядерной энергии с целью обеспечения эффективной работы автомобиля радиационной разведки RanidSONNI. Приведен опыт использования мобильной лаборатории во время проведения чемпионата Европы по футболу, который проходил в Киеве. Определены возможные направления использования мобильной лаборатории.

Ключевые слова: мобильная радиологическая лаборатория, радиационная защита, радиационный мониторинг, источники ионизирующего излучения.

() Я. Ю. Бєлов, В. І. Богорад, Т. В. Литвинська, А. В. Носовський, О. Ю. Слепченко, О. Є. Трофімова, 2012
$\mathrm{M}$ обільна радіологічна лабораторія (МРЛ) розташовується на борту обладнаного автомобіля і призначена для вирішення широкого кола завдань, пов'язаних з радіаційним моніторингом довкілля та радіаційно-небезпечних об'єктів, зокрема завдань оперативного радіаційного контролю транспортних магістралей, пошуку локальних джерел радіації, дистанційного визначення потужності дози, ідентифікації радіонуклідного складу та визначення активності радіаційного забруднення, а також проведення лабораторних досліджень на місці. Лабораторія може оснащуватися робототехнічним комплексом для пошуку, дослідження й вилучення небезпечних локальних джерел.

Мобільні лабораторії радіаційної розвідки призначені для проведення оперативної радіаційної розвідки в разі виникнення позаштатної ситуації радіаційного характеру, пошуку та визначення типу джерел іонізуючого випромінювання (ДЇВ) з метою попередження виникнення або планування заходів із зменшення наслідків радіаційної аварії

У процесі роботи мобільних засобів використовуються методи дистанційного радіаційного моніторингу, які дають змогу визначати параметри радіаційних полів на відстані, що є дуже важливим, коли прямий доступ до ДİВ ускладнений або небезпечний.

Особлива роль у запобіганні радіаційному тероризму й несанкціонованому переміщенню радіоактивних матеріалів територією контрольованого регіону відводиться мобільним засобам радіаційного контролю, що використовують методи спектрометричного дистанційного радіаційного моніторингу. В цьому разі функціонування мобільної лабораторії може здійснюватися в таких режимах:

режимі патрулювання. В даному режимі йде спостереження за переміщенням відомих джерел підвищеної радіації та пошук невідомих;

режимі активного пошуку. Якщо зафіксовано наявність підозрілого джерела радіації на території контрольованого району або отримано оперативну інформацію від правоохоронних органів про можливість його наявності, силами мобільних засобів робиться цілеспрямований пошук джерела радіації та його дистанційне дослідження;

режимі затримання. На підставі отриманих даних правоохоронні органи проводять затримання підозрілих вантажів, транспортних засобів або людей, зокрема для проведення поглибленого радіаційного контролю - оперативно на місці затримання або в спеціально обладнаному пункті. Для цього правоохоронні органи мають бути забезпечені не лише необхідною для затримання інформацією, а й відповідним устаткуванням (спеціальними засобами контролю, які носять або возять із собою).

Експлуатація мобільних лабораторій у режимі затримання допоможе у боротьбі із загрозою ядерного тероризму: виявленні підготовки терористичного акту; боротьбі 3 контрабандою радіоактивних матеріалів та їх несанкціонованим переміщенням; виявленні радіоактивного забруднення внаслідок диверсії на ранніх стадіях та сповіщенні відповідних служб і населення; ліквідації наслідків терористичних актів.

Успішність вирішення усього спектра поставлених перед мобільною лабораторією завдань залежить від наявності надійного обладнання, яке відповідало би призначенню лабораторії, кваліфікованого персоналу, який експлуатує це обладнання, та розроблених керівництв і методик щодо обслуговування обладнання, виконання вимірів, регламенту використання мобільної лабораторії.

На балансі Державного науково-технічного центру з ядерної та радіаційної безпеки (ДНТЦ ЯРБ), що 
підпорядковується Держатомрегулюванню України та НАН України, перебуває мобільна лабораторія радіаційної розвідки RanidSONNI на базі мікроавтобуса «Мерседесбенц Спринтер», основними завданнями якої є:моніторинг радіаційної обстановки довкола об'єктів радіаційно-ядерних технологій (атомних електричних станцій, дослідницьких реакторів тощо) на всіх етапах життєвого циклу;

пошук, ідентифікація та попередня категоризація втрачених Дїв;

пошук ДїВ, що можуть опинитися поза регулюючим контролем внаслідок стихійного лиха, аварійних ситуацій;

радіаційний моніторинг з метою раннього виявлення ДїВ у місцях масового скупчення людей (зокрема, під час проведення масових заходів);

підтримка Державної інспекції ядерного регулювання при проведенні інспекційних обстежень об'єктів радіаційно-ядерних технологій.

Метою статті є опис наявних у світі аналогів RanidSONNI та аналіз досвіду використання мобільної радіологічної лабораторії RanidSONNI, отриманого спеціалістами ДНТЦ ЯРБ під час проведення чемпіонату Європи з футболу, що відбувався в Києві.

Опис аналогів МРЛ RanidSONNI. У світі широко використовуються мобільні лабораторії радіаційного моніторингу. До складу вимірювального устаткування залежно від за поставлених завдань можуть входити стаціонарні та переносні гамма-спектрометричні установки, дозиметри та альфа-, бета- і гамма-радіометри, пробовідбірні пристрої.

Серед найбільш оснащених мобільних комплексів, що використовуються аварійними (аварійно-рятувальні служби Федерального агентства з атомної енергії Росії) та іншими державними службами Російської Федерації, слід виділити мобільні комплекси VISA, INSPECTOR, а також мобільну лабораторію радіаційного контролю «Мультирад ЭКО».

Комплекс VISA на базі автомобіля РЕНО В110 містить метеорологічну станцію, вимірювальну систему SYME 10 , індикатор аерозолів ВАВ-АМА 2-М. Метеорологічна станція дозволяє проводити вимірювання температури, вологості, швидкості й напряму вітру, інтенсивності опадів та автоматично вводити дані до комп'ютера й обробляти їх. Таким чином, забезпечується можливість прогнозування радіаційної обстановки з урахуванням фактичних метеоумов безпосередньо на місці аварії. За допомогою переносної вимірювальної системи SYME 10 провадять безперервне вимірювання потужності дози гамма-випромінювання (детектор $\mathrm{NaI}$ ). ІІндикатор для аерозолів ВАВ-АМА 2-М призначений для безперервного контролю радіоактивності атмосфери.

Комплекс INSPECTOR на базі автомобіля PEHO B110 складається з переносної спектрометричної системи з германієвим детектором (забезпечує вимірювання поверхневої активності радіонуклідів без відбору проб) та радіометричної лабораторії (призначена для визначення вмісту альфа-, бета-активних нуклідів у пробі повітря, грунту, рослинності). Визначення вмісту нуклідів у пробах забезпечується двома германієвими спектрометрами, що охолоджуються рідким азотом. Підготовка проб до вимірювання полягає у фільтруванні, випарюванні, зважуванні, обзоленні, нанесенні на мішені. Додаткове оснащення: витяжна шафа, муфелі, плитка, ваги, рідкий азот.

B арсеналі екіпажів мобільних радіологічних комплексів VISA та INSPECTOR є широкий набір переносних засобів контролю радіаційної обстановки, зокрема надійні прилади, призначені для робіт у місцях 3 надзвичайно складною радіаційною обстановкою. Багато з них довели свою працездатність упродовж десятиліть. Це радіометр КРБ-1, ДП-5Б (В), СРП-88 і багато інших. У ситуаціях, коли потрібно проведення точніших або спеціалізованих вимірів по окремих радіонуклідах (ізотопи плутонію й америцію, тритій тощо), використовуються складніші прилади.

Лабораторія радіаційного контролю «Мультирад ЭКО» виконує моніторинг радіаційної обстановки; пошук радіонуклідних джерел і забруднень; гамма-зйомку територій з прив'язкою результатів вимірювання до географічних координат; експресне визначення характеристик виявлених джерел і радіоактивних забруднень (радіонуклідний склад, активність та ін.); відбір та спектрометричний аналіз проб грунту, води та повітря. До складу мобільної лабораторії входять спеціалізований екологічний автомобіль 3 автономною системою електроживлення й системою підтримки температурного режиму в робочому салоні; бортовий дозиметричний комплекс із супутниковою системою визначення координат пунктів контролю за маршрутом прямування; бортовий спектрометричний комплекс; спектрометр випромінювання людини; переносний спектрометричний комплекс для визначення щільності радіоактивного забруднення та його спектральних характеристик; переносний пошуковий дозиметр-радіометр для локалізації місць забруднення; пристрої для відбору проб повітря, води й грунту; засоби вимірювання активності радону; віброзахищений бортовий комп'ютер з програмним забезпеченням.

У Сполучених Штатах Америки (штат Вірджинія) наглядовими органами у сфері безпеки поводження з ДїВ служби по радіологічному благополуччю використовуються дві мобільні лабораторії з різним набором обладнання.

Мобільна радіологічна лабораторія (МРЛ) призначена для патрулювання автомагістральних шляхів, пошуку втрачених ДїВ, виконання вимірювання під час аварій на AEC. Лабораторія оснащена гамма-спектрометром 3 германієвим детектором та берилієвим вікном (для низькоенергетичного детектування), альфа-бета лічильником системою в одному приладі для виявлення альфа- та бета-випромінювання.

Більш потужний мобільний радіологічний комплекс використовується для лабораторних аналізів з метою швидкої оцінки радіаційної обстановки під час виникнення інцидентів та підтримки прийняття рішень державними органами. Призначення комплексу - надання лабораторних послуг у разі промислової аварії на АEC; участь у щорічних навчаннях на АEC; надання аналітичних послуг для екологічної контрольної програми; підтримка в якості мобільного транспортного та вимірювального засобу структур з аварійної готовності та аварійного планування. Обладнання мобільної лабораторії складається зі стаціонарних та переносних приладів радіаційного контролю.

МРЛ Їнституту Джозеф-Стефана у Словенії створена для підтримки кризових структур у разі аварій на АЕС чи будь-якого радіаційного інциденту (наприклад, втрати радіоактивного джерела, транспортної події при транспортуванні радіоактивних матеріалів) або під час радіаційних надзвичайних ситуацій, які можуть статися на зовнішніх словенських кордонах з трансграничним або міжнаціональним радіаційним впливом. МРЛ також підготовлена для участі в антитерористичних заходах, на випадок 
загрози радіоактивного забруднення довкілля або опромінення людей. За допомогою МРЛ можна встановлювати потужність дози у визначених пунктах вимірювання та пересуваючись за заданим маршрутом (здійснюючи контроль протягом всього маршруту), рівень поверхневого забруднення, концентрацію гамма-випромінюючих радіонуклідів у зразках, індивідуальну дозу та індивідуальний рівень поверхневого забруднення шкіри або одягу, концентрацію йоду в щитовидній залозі людини, а також відібрати проби повітря, грунту, водних і сільськогосподарських продуктів з подальшим спектрометричним аналізом.

В Іспанському центрі досліджень в галузі енергетики та технологій (СІЕМАТ) створено МРЛ для швидкого розгортання в разі радіологічного інциденту, аварії на ядерному об’єкті, великомасштабної радіаційної аварії або аварії під час транспортування радіоактивних матеріалів [2]. Мобільна лабораторія уможливлює оперативне збирання даних, що може бути корисним у прийнятті рішень щодо коригуючих дій та вибору стратегії ліквідації наслідків. Лабораторія є спільним проектом кількох організацій CIEMAT та інших установ в Їспанії, зайнятих екологічними радіаційними вимірами та радіаційним захистом. У разі радіологічного інциденту МРЛ може дістатися до потрібного місця, виконати там радіологічні вимірювання, зібрати зразки та відіслати їх до стаціонарної лабораторії. Вона обладнана необхідними радіаційними вимірювальними приладами, зокрема й тими, що можна носити для вимірювання на місці. Устаткування дає змогу здійснювати безперервні вимірювання широкого спектра радіологічних параметрів: рівні випромінювання, гамма-забруднення поверхонь, забруднення повітря.

Проаналізувавши технічне оснащення мобільних лабораторій та мобільних комплексів, можна дійти висновку, що воно залежить від завдань, які планується виконувати за допомогою цього засобу, але й має загальні складові:

вимірювальне устаткування - прилади для вимірювання параметрів радіаційної обстановки та метеорологічних параметрів;

комп'ютерне та комунікаційне устаткування - термінал супутникового зв'язку, засоби стільникового зв'язку, ультракороткохвильові радіостанції, устаткування супутникової навігаційної системи GPS, сервер та допоміжні портативні комп'ютери, засоби фото- і відеозйомки;

спеціалізоване програмне забезпечення для отримання результатів вимірювання, їх обробки та аналізу, зберігання даних, демонстрації та підготовки звітних матеріалів;

допоміжні системи - система електроживлення для всього устаткування автомобіля, включаючи бензогенератор, засоби адаптації до кліматичних умов;

комплект спецодягу та дезактиваційних засобів (у разі потреби), засоби для збирання проб.

Експлуатація та обслуговування обладнання МРЛ забезпечується низкою документів щодо якості вимірювань і організації технічного обслуговування обладнання, порядку дій персоналу МРЛ у процесі виконання тих чи інших завдань.

Технічне оснащення мобільної радіологічної лабораторії RanidSONNI. RanidSONNI - це сучасна модель машини для виконання радіологічних вимірювань (рис. 1), призначена для виявлення та аналізу потенційних радіологічних та ядерних загроз, таких як викид радіоактивних матеріалів з об’єктів ядерно-паливного циклу, шо призвів до забруднення радіоактивними речовинами довкілля. Універсальна МРЛ оснащена високоякісним сучасним

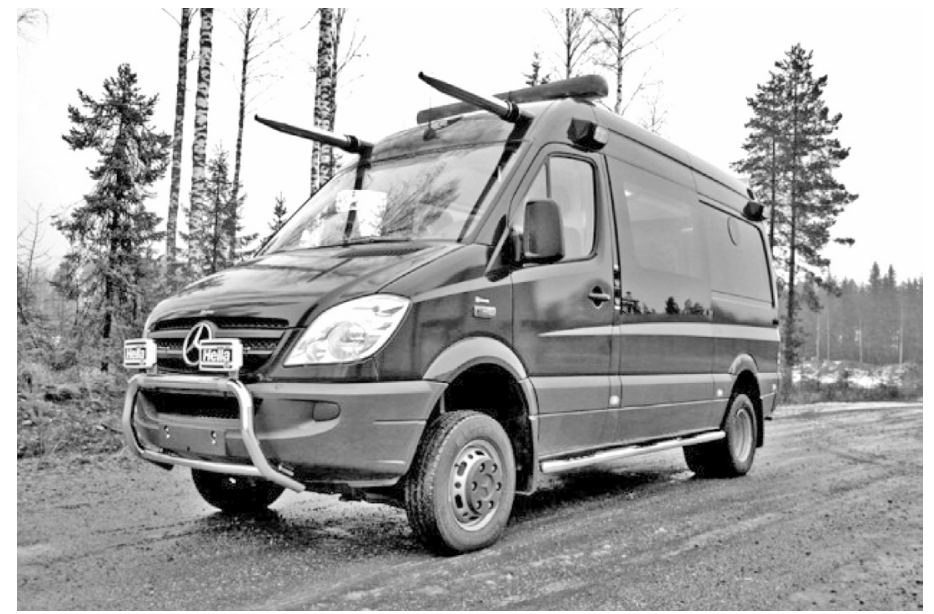

Рис. 1. Машина радіаційної розвідки RanidSONNI

устаткуванням, що забезпечує виконання основних завдань радіаційного моніторингу.

Система вимірювань на місцевості має два великі сцинтиляційні детектори $\mathrm{NaI}(\mathrm{Tl})$, змонтовані на протилежних бічних стінках RanidSONNI (рис. 2). Сталеві 10-міліметрові екрани навколо детекторів створюють 180-градусне поле огляду, що відкривається назовні. Подібна конфігурація дає гарну можливість виявлення та встановлення напрямку на джерела випромінювання.

У передній частині машини (над передніми сидіннями, між ними) встановлено детектор RanidPro $100 \mathrm{LaBr}_{3}$. Детектор розташований у захисному кожусі 10 мм завтовшки для захисту від фонового випромінювання з боків, забезпечуючи найвищу чутливість у напрямку руху автомобілю.

Подібна система $з$ трьох детекторів, що контролюють різні напрямки, дає змогу здійснювати сканування місця інциденту з відстані та виділяти підозрілі об'єкти 3-поміж інших подібних (наприклад, розшукувані автомобілі в транспортному потоці).

Машина оснащена двома стаціонарними пробовідбірниками. Фільтри розміщені в пластикових касетах, що полегшує роботу з пробами в машині, під час руху. Завдяки особливій конструкції касети з фільтрами проводити підготовку проб перед вимірюваннями немає потреби. У сильно забруднених районах відфільтроване повітря із стаціонарних пробовідбірників може подаватися до салону.

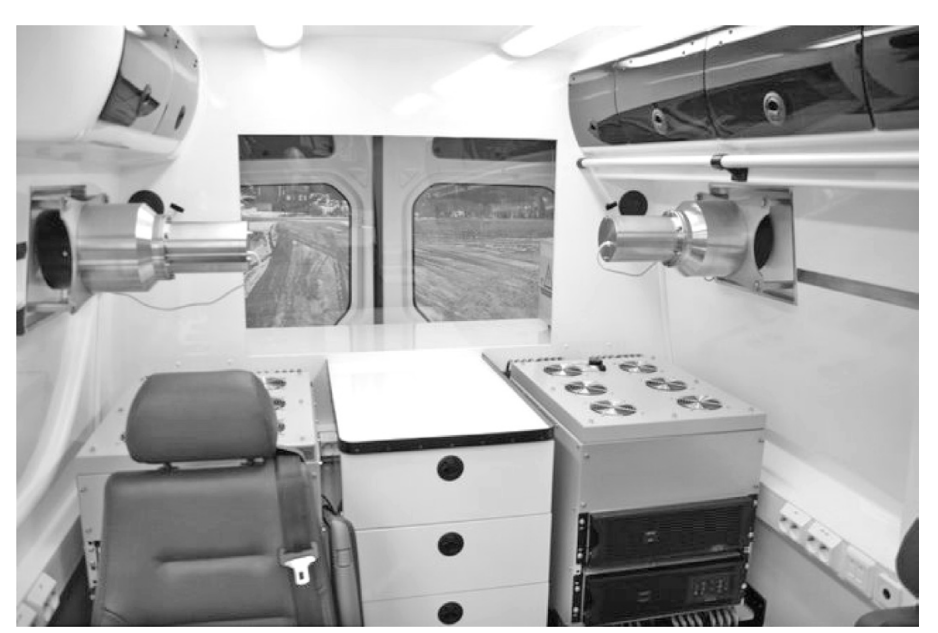

Рис. 2. Сцинтиляційні детектори (NaI) з 180-градусним полем огляду 


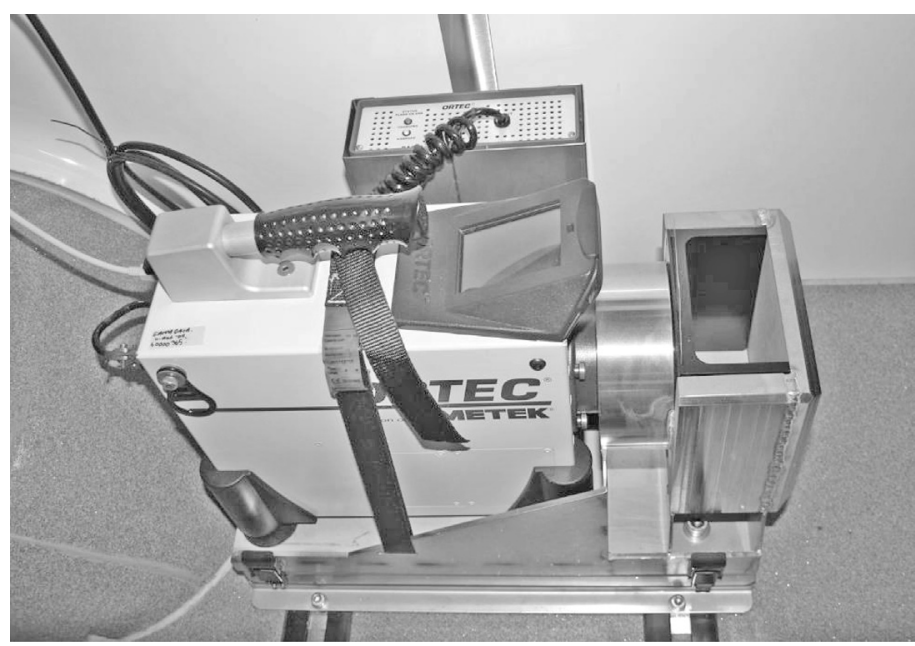

Рис. 3. Переносний детектор/ідентифікатор нуклідів на основі особливо чистого германію марки ORTEC

Додаткове повітря, що втягується пробовідбірниками, створює надмірний тиск, який перешкоджає просочитися в салон забрудненому повітрю крізь нещільно закриті двері та вікна.

Для відбирання проб повітря машина обладнана переносним устаткуванням. Автономний пробовідбірник має невеликі розміри й живиться від акумуляторних батарей, завдяки чому він може бути встановлений у необхідному місці для самостійного відбирання проб. Фільтри також поміщені в пластикові касети, що полегшує роботу з пробами.

Система вимірювання проб має детектор на основі чистого германію для гамма-спектрометрії проб (рис. 3); під час пошукових робіт з виходом з машини він використовується як переносний прилад подвійного призначення.

Система обробки даних містить один основний сервер типу HPML350G6 E552 і три робочі станції. Сервер використовує комп'ютерні апаратні засоби, працює на операційній системі сімейства Linux, обробляє та зберігає всі дані вимірювань, що надходять від різних детекторів та вимірювальних систем. Дані, що надходять з детекторів, аналізуються програмою ідентифікації радіонуклідів Vasikka. Сервер сполучений з усіма джерелами інформаціï через комунікаційну мережу (з апаратним підключенням та використанням протоколу TCP/IP і шини USB).

Робочі станції працюють на операційній системі Windows Vista. Вони з'єднані з основним сервером через локальну мережу. Всі робочі станції можуть працювати незалежно й обробляти дані вимірювань через локальну мережу. Робочі станції встановлюються на столах операторів (рис. 4).

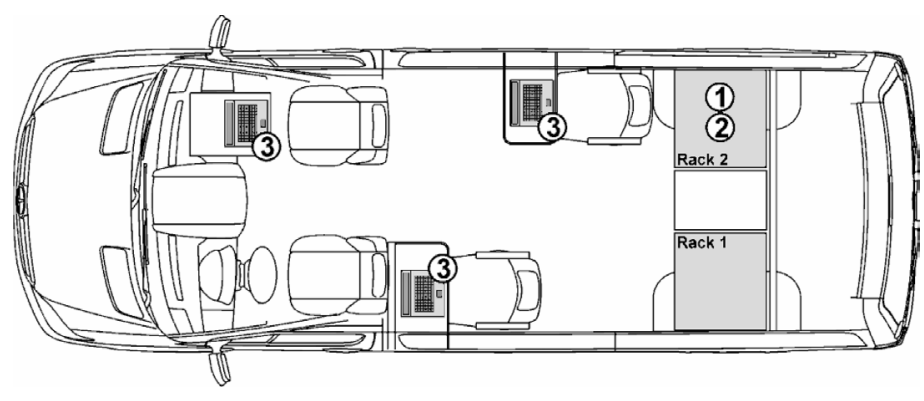

Рис. 4. Схема розміщення елементів системи обробки даних: 1 - сервер; 2 - джерела безперебійного живлення; 3 - робочі станції

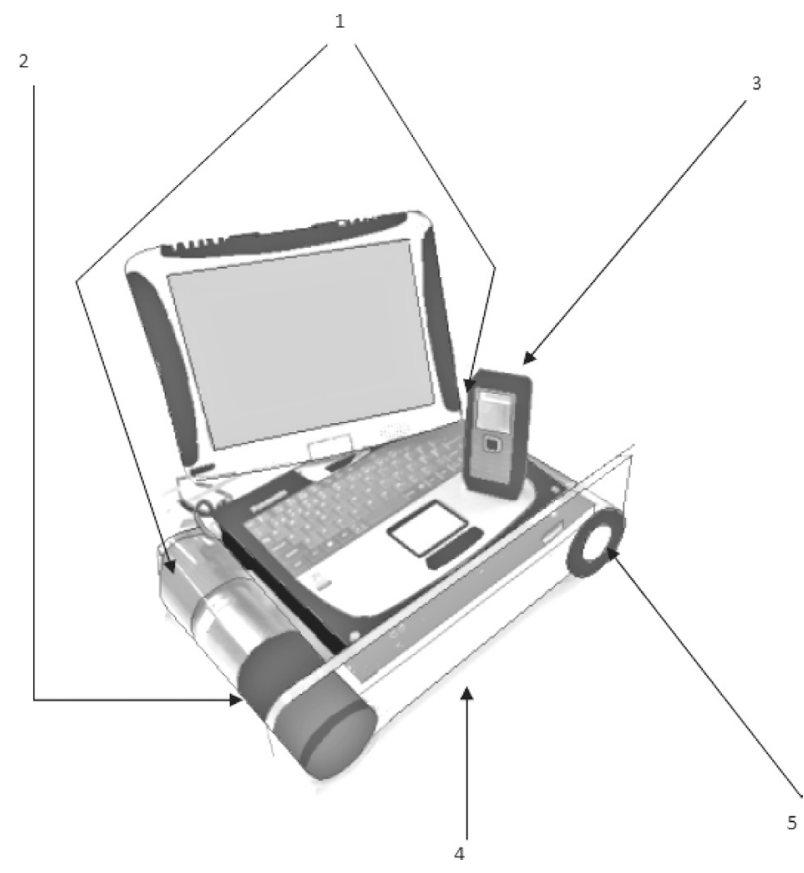

Рис. 5. Переносна вимірювальна система Vasikka: 1 - цифровий багатоканальний аналізатор; 2 - детектор нейтронів; 3 - комп'ютер віддаленого керування; 4 - плексигласова рама; 5 - детектор гамма-випромінювання на основі $\mathrm{LaBr}$

До комплекту технічних засобів МРЛ RanidSONNI для оперативної оцінки радіаційної обстановки на місці входить переносна вимірювальна система Vasikka (рис. 5), що розміщується в рюкзаку. Вона складається з персонального комп'ютера, детекторів гамма- і нейтронного випромінювання з відповідною електронікою. Для віддаленого керування системою можуть використовуватися мобільний телефон або кишеньковий комп'ютер (електронний записник). Система безперервно збирає та аналізує радіаційну інформацію, яка надходить до детекторів. Усі зібрані дані також накопичуються в базі даних для подальшого перегляду або детального аналізу. Система Vasikka знаходиться під керуванням спеціально розробленого програмного забезпечення для виконання польової спектрометрії, проведення радіаційного контролю в режимі реального часу й передачі даних. Аналогічне програмне забезпечення встановлено на сервері та робочих станціях мобільної лабораторії RanidSONNI.

Машина оснащена системою бездротового внутрішнього зв'язку, розрахованого максимум на чотири користувача. До неї входить один базовий блок, до якого можуть бути підключені чотири телефонні трубки. Єдиний блок антени й приймача GPS змонтований на даху машини. Дані про місцезнаходження машини зберігаються в базі даних.

Компресорний холодильник Waeco CoolFreeze CDF-35 місткістю 31 л, встановлений у машині, використовується для зберігання проб. У ньому підтримується температура від $-5^{\circ} \mathrm{C}$ до $+10{ }^{\circ} \mathrm{C}$. Живиться від джерела постійного струму автомобіля $12 \mathrm{~B}$.

До складу обладнання мобільної лабораторії RanidSONN входить орієнтована за рухом камера спостереження (IPкамера Bosch DinionXF), цифрові зображення з якої зберігаються на сервері.

3 наведеного опису технічних можливостей мобільної лабораторії RanidSONN видно, що ії оснащення не відрізняється від оснащення аналогічних мобільних лабораторій. Особливістю цієї МРЛ насамперед є досить потужна установка 
з відбирання проб повітря з регульованою витратою від 10 до $40 \mathrm{~m}^{3}$ /год. Слід також відмітити можливості нарощувати технічне та програмне оснащення системи завдяки потужному серверу та досить відкритій системі приєднання нових пристроїв до програмного забезпечення. 3 огляду на різноплановість завдань, покладених на мобільну лабораторію RanidSONNI, передбачається додатково оснастити іï низкою переносних приладів для більш ефективного моніторингу радіаційної обстановки навколо об’єктів радіаційноядерних технологій (АЕС, дослідницьких реакторів тощо) у процесі нормальної експлуатації та в разі можливих інцидентів, забезпечуючи підтримку аварійного реагування.

Методичне забезпечення МРЛ представлено керівництвами користувачів на кожен з приладів радіаційного моніторингу та додаткове устаткування. Крім того, є керівництво із запуску всього обладнання мобільної лабораторії RanidSONNI та керівництво користувача програмного забезпечення Vasikka, під керуванням якого працює все вимірювальне обладнання, крім детектора на основі чистого германію для гамма-спектрометрії проб, який має своє методичне та програмне забезпечення.

Для забезпечення експлуатації мобільної лабораторії RanidSONNI проведено метрологічну атестацію вимірювального обладнання, теоретичну та практичну підготовку персоналу (в кількості двох екіпажів), додаткове оснащення програмним забезпеченням, шо дозволило дистанційно передавати дані в он-лайн режимі щодо місця знаходження автомобіля та результати вимірювань з сервера МРЛ на сервер ДНТЦ ЯРБ.

Досвід використання мобільної радіологічної лабораторій RanidSONNI отримано при забезпеченні системного радіаційного моніторингу території фан-зони в м. Києві під час проведення в Україні фінальної частини чемпіонату Європи з футболу СВРО-2012.

Для радіаційного обстеження визначених ділянок фанзони застосовувалося бортове обладнання лабораторії в складі двох багатоканальних бортових детекторів $\mathrm{NaI}(\mathrm{Tl})$ та одного багатоканального фронтального детектора на основі RanidPro 100 на основі $\mathrm{LaBr}_{3}$. Крім того, у добовому моніторингу використовувалися переносні засоби вимірювань: багатоканальні переносні спектрометри $з$ детекторами гамма-випромінювання та нейтронів Vasikka RanidPro 200 і багатоканальний спектрометр Ortec Detective-DX на основі детектора з надчистим германієм.

На підготовчій фазі до ЄВРО-2012 були отримані картограми нульового фону на маршрутах патрулювання, підтверджені в день відкриття фінальної частини чемпіонату шляхом повторного зняття «нульового фону» території навколо стадіону «Олімпійський», території фанзони та прилеглих вулиць - за допомогою стаціонарних засобів мобільної лабораторії RanidSONNI (бортового обладнання) та переносних приладів (рис. 6, 7). На цій фазі виявлено місця підвищеного фону на вулицях міста та ідентифіковано їх природне походження, пов'язане з використанням будівельних матеріалів з підвищеним вмістом природних радіонуклідів, таких як радій та торій.

Радіаційне обстеження проводилось щоденно, включаючи вихідні та святкові дні, двічі на добу. Зранку територія обстежувалася вздовж периметра фан-зони за допомогою переносних спектрометрів (перевірялися місця можливого знаходження джерел іонізуючого випромінювання - припарковані поблизу автомобілі, контейнери для сміття тощо), у другій половині дня -

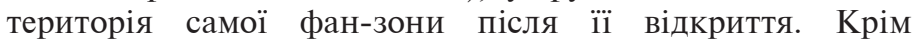

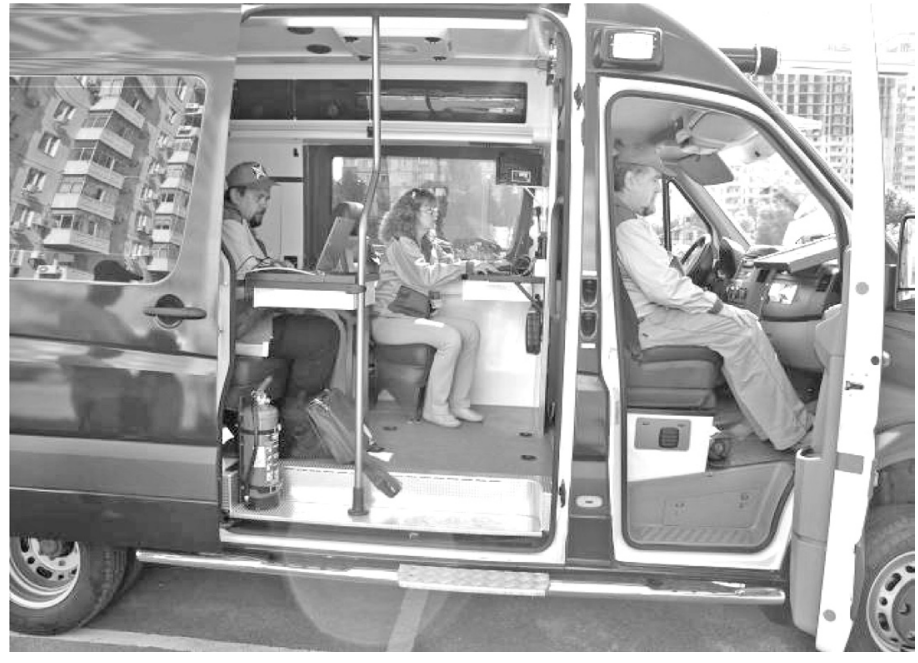

Рис. 6. Екіпаж лабораторії готується до виїзду

визначених маршрутів проводилося радіаційне обстеження вулиць міста на шляху слідування автомобіля до місця його дислокації за допомогою бортових приладів. Маршрути обиралися заздалегідь так, щоб охопити якомога більше вулиць та площ міста. Результати передавалися дистанційно на сервер ДНТЦ ЯРБ у спеціально створену базу даних, де вони доступні для подальшого аналізу, а також шоденно доповідалися керівництву Держатомрегулювання України.

За результатами проведених вимірювань, під час чергувань мобільної лабораторії RanidSONNI інцидентів 3 незаконним застосуванням джерел іонізуючого випромінювання не сталося, радіаційна обстановка на визначених маршрутах знаходилася в межах «нульового фону». Поодинокі сплески гамма-випромінювання були пов'язані з появою в місцях скупчення людей осіб, які приймали радіофармпрепарати на кшталт фтору-18 (дане ДїВ чітко визначалось за допомогою парку приладів радіаційного контролю RanidSONNI). У кількох випадках ідентифікувалися промислові ДїВ (америцій-241), що пов'язано із знаходженням в місцях, де проводились виміри, спеціалізованих автомобілів, на борту яких знаходилися прилади, в яких використовуються промислові ДїВ.

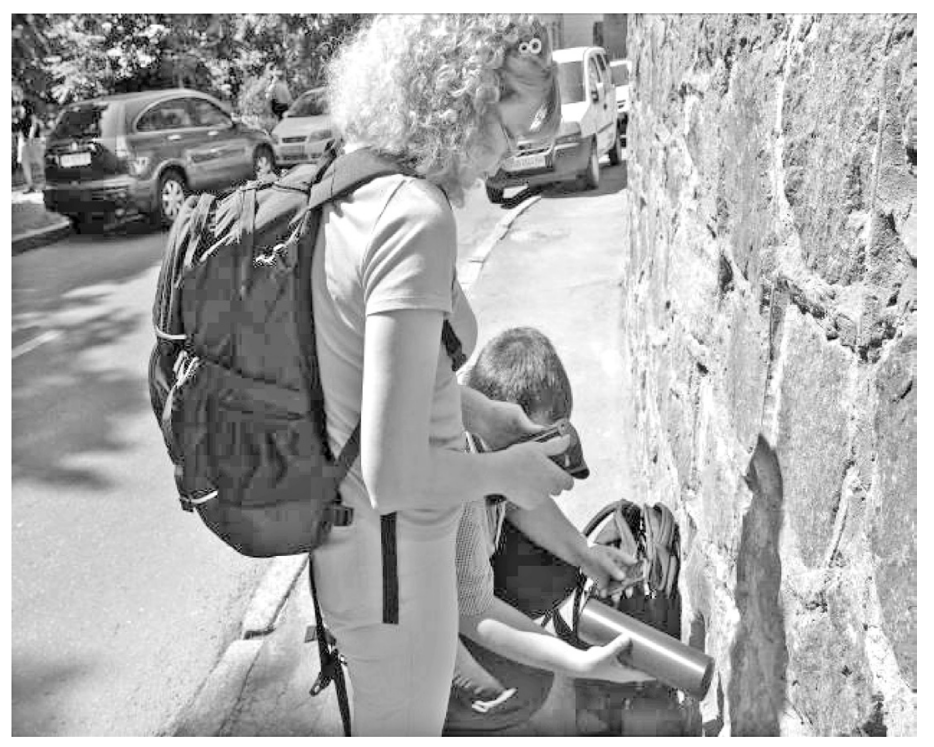

Рис. 7. Обстеження території за допомогою переносних приладів 


\section{Висновки}

Результати аналізу технічних можливостей мобільної лабораторії RanidSONNİ при здійсненні радіаційного обстеження території під час проведення в Україні фінальної частини чемпіонату Європи з футболу СВРО-2012 свідчать, що її оснащення дозволяє проводити ефективний контроль за радіаційною обстановкою в місцях великого скупчення людей, знаходити джерела іонізуючого випромінювання та проводити оперативну ідентифікацію їх радіонуклідного складу. Останне можливо навіть тоді, коли потужність дози залишається на рівні нульового фону.

За результатами аналізу проведених робіт з підготовки до використання та використання мобільної лабораторії RanidSONNİ для забезпечення радіаційного моніторингу встановлено, що вкрай важливе значення має саме підготовчий період, на якому розробляється програма досліджень, знімається нульовий фон та встановлюються рівні реагування. Саме завдяки правильно організованому начальному періоду стає можливим коректно ідентифікувати появу нових ДІВВ і визначитися з пов'язаними з ним ризиками.

Перший досвід експлуатації мобільної лабораторії RanidSONNİ показав, шо за її допомогою можна виконувати значно ширше коло завдань з підтримки регулюючої діяльності Держатомрегулювання, ніж пошук ДїВ, що знаходяться в несанкціонованому обігу, а саме:

незалежний контроль за дотриманням допустимих рівнів концентрації радіонуклідів у повітрі в межах визначених санітарно-захисних зон та зон спостереження AEC;

контроль радіаційного фактору за санітарно-гігієнічним станом підприємств, які використовують ДїВ;

контроль за дотриманням правил безпечного перевезення радіоактивних матеріалів;

вивчення санітарно-гігієнічного стану територій.

\section{Список використаної літератури}

1. Розробка регламенту використання мобільної лабораторії з метою оцінки радіаційного стану територій та пошуку «покинутих» ДїВ. Технічне завдання на виконання науково-дослідної роботи. Додаток 1 до договору № 03/1-2011/11-03 від 22.07.2011. К. : ДНТЦ ЯРБ, 2011

2. Environmental mobile radiation protection unit at ciemat/ E. Correa, C. Sancho, J. C. S6ez, A. Blvarez, D. Burgos // CIEMAT Servicio de Protecciyn Radiolygica, Avda. Complutense 22, 28040 Madrid, Spain.

3. ISO 5725-1:1994 Accuracy (trueness and precision) of measurement methods and results. - Part 1: General principles and definitions.

4. Методика выполнения измерений мощности эквивалентной дозы гамма-излучения дозиметрами и дозиметрами-радиометрами / МВИ. МН 2513-2006. - Гомель, 2005. - 11 с.

5. Руководство по мониторингу при ядерных или радиашионных авариях: IAEA-TECDOC-1092/R. - Вена: МАГАТЭ, 2002.

6. Инструкция по наземному обследованию радиационной обстановки на загрязненной территории / Межведомственная комиссия по радиационному контролю природной среды. - М., 1989.

7. Оперативная оценка доз облучения населения при радиоактивном загрязнении территории воздушным путем: Методические указания МУ 2.6.1.2153-06. - М., 2007.

8. Критерии оценки экологической обстановки территорий для выявления зон чрезвычайной экологической ситуации и зон экологического бедствия / Минприроды РФ. - М., 1992.

9. ГОСТ Р 22.2.04-94. Безопасность в чрезвычайных ситуациях. Техногенные аварии и катастрофы. Метрологическое обеспечение контроля состояния сложных технических систем. Основные положения и правила.

10. ГОСТ 27451-87. Средства измерений ионизирующих изучений. Общие технические условия. 